\title{
Role of Collagen in Retinoic Acid-induced Differentiation and Down-regulation of TGF- $\beta$ Receptors in Rat Preosteoblastic RCT-1 Cells
}

\author{
YOSHIAKI KODAMA, YASUHIRO TAKEUCHI*, TOMOKO KIKUCHI*, \\ TAKAHIDE KUROKAWA, TOSHIRO FUJITA*, AND TOSHIO MATSUMOTO* \\ Department of Orthopedic Surgery and *Fourth Department of Internal Medicine, \\ University of Tokyo School of Medicine, Tokyo 112, Japan
}

\begin{abstract}
Retinoic acid induces differentiation of preosteoblastic cells. We have demonstrated that osteoblastic differentiation and down-regulation of transforming growth factor (TGF)- $\beta$ receptors requires the interaction of type I collagen with $\alpha 2 \beta 1$ integrin (J Biol Chem 271: 3938-3944, 1996). The purpose of this study was to clarify the role of collagen in retinoic acid-induced differentiation and down-regulation of TGF- $\beta$ receptors using preosteoblastic RCT-1 cells. Retinoic acid enhanced the expression of alkaline phosphatase and type I collagen, and reduced TGF- $\beta$ receptors in these cells. Inhibiting collagen synthesis abolished these changes. Because TGF- $\beta$ inhibits osteoblastic differentiation, the changes described here may contribute to the osteoblastic differentiation by retinoic acid.
\end{abstract}

Key words: Osteoblastic differentiation, Retinoic acid, Alkaline phosphatase, Type I collagen, Transforming growth factor $-\beta$ (TGF- $\beta$ ) receptors

(Endocrine Journal 44: 375-381, 1997)

RETINOIC acid induces the expression of alkaline phosphatase (ALP) and enhances osteoblastic differentiation of pluripotent mesenchymal cells [1, 3] and preosteoblastic cells [5, 19]. Retinoic acid also enhances the expression of type I collagen in preosteoblastic cells [5]. It has been reported that retinoic acid-induced osteoblastic differentiation of mouse C3H10T1/2 embryonic fibroblasts and rat C26 preosteoblastic cells is associated with downregulation of transforming growth factor (TGF)- $\beta$ receptors [3]. TGF- $\beta$ is one of the most potent stimulators of type I collagen synthesis in various types of cells $[8,17]$, and the most pronounced

Received: November 8, 1996

Accepted: December 20, 1996

Correspondence to: Dr. Yasuhiro TAKEUCHI, Fourth Department of Internal Medicine, University of Tokyo School of Medicine, 3-28-6 Mejirodai, Bunkyo-ku, Tokyo 112, Japan effect of TGF- $\beta$ in bone is the stimulation of matrix protein synthesis including type I collagen, proteoglycans and fibronectin $[7,9,18]$. Our recent observations demonstrated that mouse osteoblastic MC3T3-E1 cells undergo differentiation during long-term culture, that the differentiation of these cells is closely associated with down-regulation of cell surface TGF- $\beta$ receptors, and that the differentiation and the down-regulation of TGF- $\beta$ receptors in MC3T3-E1 cells is dependent upon the synthesis of type I collagen [16]. In addition, these effects of collagen are found to be mediated by the interaction of type I collagen with these cells via the binding of the DGEA motif on the collagen molecule to $\alpha 2 \beta 1$ integrin [16]. It is, therefore, possible that the effects of retinoic acid on the osteoblastic differentiation and down-regulation of TGF- $\beta$ receptors may also be mediated by its effect on collagen production. The present study was undertaken to clarify the role of collagen in retinoic 
acid-induced differentiation and associated changes in TGF- $\beta$ receptors by using preosteoblastic RCT-1 cells.

\section{Materials and Methods}

\section{Materials}

RCT-1 and RCT- 3 cells were kindly given by Dr. G. A. Rodan (Merck Research Laboratories, West Point, PA) and Dr. M. Noda (Tokyo Medical and Dental University, Tokyo, Japan). Retinoic acid was purchased from Sigma (St. Louis, MI). LAzetidine-2-carboxylic acid was purchased from WAKO Pure Chemicals (Osaka, Japan), recombinant human TGF- $\beta 1$ from Cosmo-Bio Co. (Tokyo, Japan), [125I]TGF- $\beta 1$ and [32P]dCTP from Amersham Japan, [35S]sulfuric acid from DuPont/ NEN and disuccinimidyl suberate from Pierce (Rockford, IL).

\section{Cell culture}

Preosteoblastic cell line RCT-1 was maintained in RPMI 1640 medium containing $10 \%$ fetal bovine serum (FBS), $100 \mathrm{U} / \mathrm{m} l$ penicillin, and $100 \mu \mathrm{g} / \mathrm{ml}$ streptomycin sulfate. Osteoblastic cell line RCT-3 was cultured in $\alpha$-modified minimum essential medium containing 10\% FBS, 25mM HEPES, 100 $\mathrm{U} / \mathrm{ml}$ penicillin, and $100 \mu \mathrm{g} / \mathrm{ml}$ streptomycin sulfate.

Collagen production was blocked by adding 0.3 mM L-azetidine-2-carboxylic acid to culture media. L-Azetidine-2-carboxylic acid is a non-hydrolyzable proline analog that is incorporated into the collagen molecule and inhibits the synthesis of collagen. Simultaneous addition of a 10 times higher concentration of proline ( $3 \mathrm{mM})$, collagen synthesis can be restored [4].

\section{RNA extraction}

Total RNA was extracted from RCT-1 cells treated with or without $1 \mu \mathrm{M}$ retinoic acid for 2 or 4 days by the acid guanidine phenol-chloroform method. Samples were electrophoresed and transferred to nylon membranes (Hybond) by capillary action in 20 times-concentrated standard saline citrate (SSC, $0.15 \mathrm{M} \mathrm{NaCl}, 15 \mathrm{mM}$ trisodium citrate, $\mathrm{pH}$ 7.0). Filters were baked under ultraviolet waves.

\section{Northern blot analysis}

mRNA immobilized on nylon membrane was hybridized at $42^{\circ} \mathrm{C}$ for $16 \mathrm{~h}$ with the cDNA probes for rat ALP (kindly donated by Drs. M. Noda and G.A. Rodan) and $\alpha 1$ (I) procollagen (a gift from Dr. B. E. Kream, University of Connecticut Health Center, Farmington, CT). The cDNA probes were labeled with [32P]dCTP by random hexanucleotide primer extension with the Megaprime labeling system (Amersham Japan). After hybridization, the membranes were washed several times with SSC buffer containing $0.1 \%$ sodium dodecyl sulfate, and were subject to autoradiography.

\section{Alkaline phosphatase activity}

Cells were washed twice with ice-cold phosphate buffered saline and scraped into $10 \mathrm{mM}$ Tris- $\mathrm{HCl}$ containing $2 \mathrm{mM} \mathrm{MgCl}_{2}$ and $0.05 \%$ Triton X-100, $\mathrm{pH}$ 8.2. The cell suspension was homogenized with a Pellet Pestle (Kontes, Vineland, NJ) on ice following two cycles of freezing and thawing. Aliquots of supernatants were subject to protein assay with a Bio-Rad kit according to Bradford's method and to ALP activity measurement [10]. In brief, the assay mixture contained $10 \mathrm{mM}$ pnitrophenyl phosphate in $0.1 \mathrm{M}$ sodium carbonate buffer, $\mathrm{pH} 10$, supplemented with $1 \mathrm{mM} \mathrm{MgCl}$, followed by an incubation at $37^{\circ} \mathrm{C}$ for $30 \mathrm{~min}$. After adding $0.1 \mathrm{M} \mathrm{NaOH}$, the amount of $\mathrm{p}$ nitrophenol liberated was measured with a spectrophotometer.

\section{Affinity crosslinking analyses of cell-surface TGF- $\beta$ receptors}

RCT- 1 and RCT- 3 cells in 10-cm culture dishes were washed twice with ice-cold phosphate buffered saline. Binding of 100 pM [125I]TGF- $\beta 1$ (total radioactivity of approximately $200,000 \mathrm{cpm}$ ) to cells was performed in a buffer containing 128 $\mathrm{mM} \mathrm{NaCl}, 5 \mathrm{mM} \mathrm{KCl}, 5 \mathrm{mM} \mathrm{MgSO}_{4}, 1.3 \mathrm{mM} \mathrm{CaCl}_{2}$ and $25 \mathrm{mM}$ HEPES, pH 7.4 containing $0.3 \%$ bovine serum albumin at $4{ }^{\circ} \mathrm{C}$ for $4 \mathrm{~h}$ as reported previously [15]. After washing the cells with icecold PBS, bound [125I]TGF- $\beta 1$ was chemically 
crosslinked in $2 \mathrm{ml}$ of phosphate buffered saline containing $0.3 \mathrm{mM}$ disuccinimidyl suberate at $4{ }^{\circ} \mathrm{C}$ for $20 \mathrm{~min}$. The chemical reaction was terminated by adding $200 \mu l$ quenching buffer ( $100 \mathrm{mM}$ Tris$\mathrm{HCl}, \mathrm{pH} 7.5,200 \mathrm{mM}$ glycine and $20 \mathrm{mM}$ EDTA), and the cells were kept at room temperature for 1 min. After washing twice with phosphate buffered saline, the cells were scraped into a tube on ice containing $1 \mathrm{ml}$ phosphate buffered saline with 1 mM EDTA and protease inhibitors mixture of 1 $\mathrm{mM}$ phenylmethylsulfonyl fluoride, $10 \mathrm{mM} \mathrm{N}$ ethylmaleimide and $10 \mu \mathrm{g} / \mathrm{ml}$ pepstatin A. Cells were then collected by centrifugation, and solubilized in $40-100 \mu l$ ice-cold lysis buffer (10 $\mathrm{mM}$ Tris- $\mathrm{HCl}, \mathrm{pH} 7.5,0.5 \%$ Nonidet $\mathrm{P}-40,1 \mathrm{mM}$ EDTA and protease inhibitors) for $40 \mathrm{~min}$ on ice. The lysates were centrifuged and supernatants were subject to SDS-polyacrylamide gel electrophoresis with a $10 \%$ polyacrylamide gel followed by autoradiography. Loading samples were adjusted to contain the same amount of protein.

\section{Assays for proteoglycan synthesis}

Synthesis of proteoglycans by RCT- 1 and RCT-3 cells was determined as described previously [14]. Cells were labeled with $100 \mu \mathrm{Ci} / \mathrm{ml}$ [35S]sulfate for $1 \mathrm{~h}$ at $37^{\circ} \mathrm{C}$ after treatment with 100 pM TGF- $\beta 1$. The cell layer and media were simultaneously extracted with $4 \mathrm{M}$ guanidine $\mathrm{HCl}, \mathrm{pH}$ 6.0, containing $0.5 \%$ Triton $\mathrm{X}-100,50 \mathrm{mM}$ sodium acetate, $50 \mathrm{mM}$ EDTA and protease inhibitors. Unincorporated isotopes were removed by Sephadex G-50 (Pharmacia) column chromatography eluted with $7 \mathrm{M}$ urea buffer containing $0.25 \mathrm{M} \mathrm{NaCl}, 50 \mathrm{mM}$ sodium acetate and $0.5 \%$ Triton $\mathrm{X}-100, \mathrm{pH} 6.0$. Void fractions containing proteoglycans were collected and the radioactivity in each eluent was counted.

\section{Results}

\section{Osteoblastic differentiation of preosteoblastic RCT-1} cells by retinoic acid

RCT-1 cells were established from rat calvariae and are shown to express preosteoblastic phenotypes [5]. As reported previously [5], the expression of ALP mRNA was enhanced 2 days after the addition of $1 \mu \mathrm{M}$ retinoic acid, and remained high after 4 days (Fig. 1). As a result, ALP activity of RCT-1 cells after treatment with 1 $\mu \mathrm{M}$ retinoic acid for 4 days $(0.10 \pm 0.02$ vs. $0.96 \pm$ $0.22 \mathrm{nmol} / \mathrm{min} / \mu \mathrm{g}$-protein in the absence and presence of retinoic acid, respectively, data are means $\pm S E M, n=3$ ) was stimulated to a level similar to that of RCT-3 cells having osteoblast markers $(0.68 \pm 0.07 \mathrm{nmol} / \mathrm{min} / \mu \mathrm{g}$-protein). In contrast, the high ALP activity in RCT-3 cells was not further enhanced by retinoic acid $(0.76 \pm 0.02 \mathrm{nmol} / \mathrm{min} /$ $\mu \mathrm{g}$-protein). The expression of procollagen $\alpha 1$ (I) mRNA in RCT-1 cells was also enhanced in a time-

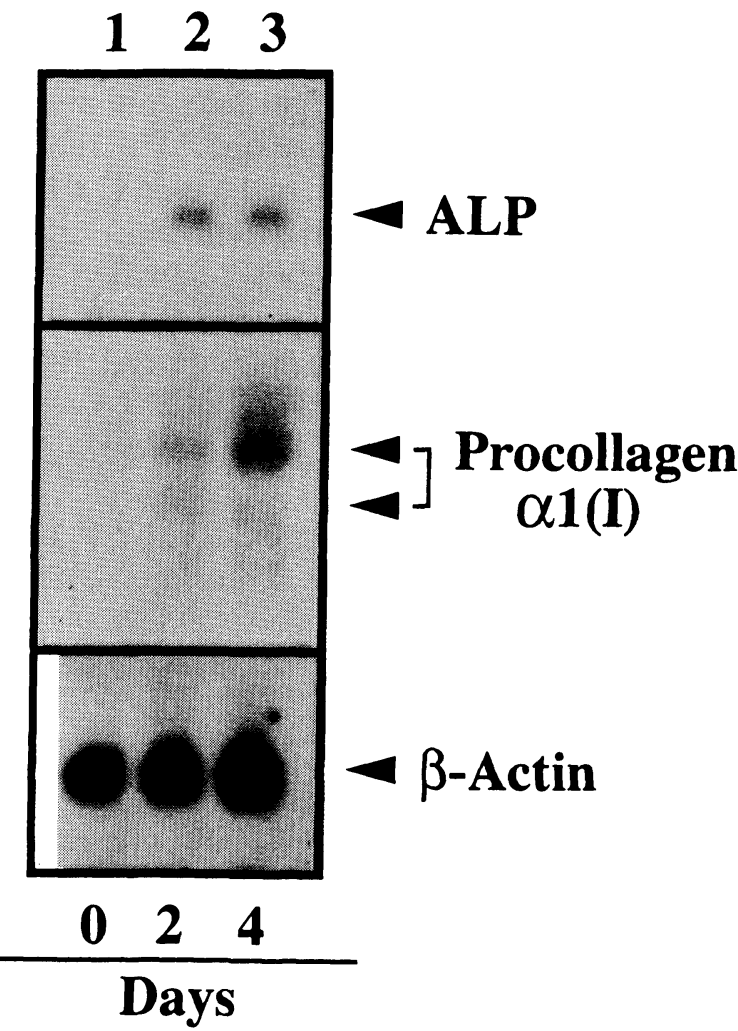

Fig. 1. Effect of retinoic acid on mRNA expression of alkaline phosphatase and $\alpha 1(\mathrm{I})$ procollagen in RCT1 cells. RCT- 1 cells were treated with $1 \mu \mathrm{M}$ retinoic acid for 0 (lane 1), 2 (lane 2) and 4 days (lane 3 ). Ten $\mu \mathrm{g}$ of total RNA was electrophoresed in $1.5 \%$ agarose gel and was transferred onto a nylon membrane followed by hybridization with the radiolabeled cDNA probes for rat alkaline phosphatase and $\alpha 1$ (I) procollagen. mRNA expression of $\beta$-actin is indicated in each lane as an internal reference of a housekeeping gene. 
dependent manner by retinoic acid (Fig. 1). These results confirm that RCT-1 cells have a preosteoblastic nature and can be differentiated to express osteoblasts markers by retinoic acid.

\section{Relationship between collagen and retinoic acid- induced development of ALP activity}

We and others have reported that the induction of ALP activity in osteoblastic MC3T3-E1 cells is dependent upon collagen production $[2,16]$. In order to clarify whether retinoic acid-induced development of ALP activity in RCT-1 cells is also dependent upon collagen production, the effect of a collagen synthesis inhibitor on ALP activity was examined. The addition of $0.3 \mathrm{mM}$ L-azetidine-2carboxylic acid, a proline analog that is incorporated into collagen instead of proline and inhibits collagen production, partially inhibited the retinoic acid-induced increase in ALP activity in RCT-1 cells after 4 days of treatment (Table 1). Simultaneous addition of an excess amount of Lproline ( $3 \mathrm{mM}$ ) with L-azetidine-2-carboxylic acid restored ALP activity, suggesting that collagen production is at least in part required for the stimulation of ALP activity in RCT-1 cells by retinoic acid.

Down-regulation of TGF- $\beta$ receptors on RCT-1 cells induced by retinoic acid

Types I and II TGF- $\beta$ receptors cross-linked with
[125I]TGF- $\beta 1$ were abundantly expressed on RCT-1 cells (Fig. 2). The induction of osteoblastic differentiation by treatment with retinoic acid for 4 days caused a decrease in the cell surface expression of both types of TGF- $\beta$ receptors in RCT1 cells to a similar level to that in osteoblastic RCT-3 cells without treatment (Fig. 2).

The changes in TGF- $\beta$ receptors were closely correlated with changes in TGF- $\beta$ actions in RCT-1 cells. Proteoglycan synthesis as determined by the incorporation of $\left[{ }^{35} \mathrm{~S}\right]$ sulfate was stimulated in response to $100 \mathrm{pM}$ TGF- $\beta 1$ before treatment with retinoic acid, whereas the same concentration of TGF- $\beta 1$ had no effect on proteoglycan synthesis when RCT-1 cells were treated with retinoic acid (1.50 \pm 0.07 -fold vs. $0.94 \pm 0.01$-fold stimulation by 100 pM TGF- $\beta 1$ in the absence and presence of 1 $\mu \mathrm{M}$ retinoic acid, respectively, $P<0.01$ ). In parallel with the low level of cell surface TGF- $\beta$ receptors on RCT-3 cells, proteoglycan synthesis was not affected by 100 pM TGF- $\beta 1$ in these cells $(0.94 \pm$ 0.03 vs. $1.03 \pm 0.04$-fold stimulation by 100 pM TGF$\beta 1$ in the absence and presence of $1 \mu \mathrm{M}$ retinoic acid, respectively). Furthermore, although RCT-3 cells responded well to recombinant human bone morphogenetic protein-2, one of the most potent stimulants for osteoblastic differentiation, to express higher ALP activity, 100 pM TGF- $\beta 1$ had no effects on ALP activity in these cells, as was seen in RCT-1 cells treated with retinoic acid (data not shown).

The changes in TGF- $\beta$ receptors during retinoic

Table 1. Effect of retinoic acid on alkaline phosphatase activity of RCT-1 cells, and effect of collagen synthesis inhibitors on retinoic acid-induced stimulation of alkaline phosphatase activity in RCT-1

\begin{tabular}{ccc}
\hline Retinoic acid & Inhibitor & $\begin{array}{c}\text { Alkaline phosphatase activity } \\
(\mathrm{nmol} / \mathrm{min} / \mu \mathrm{g} \text {-protein })\end{array}$ \\
\hline- & - & $0.02 \pm 0.01$ \\
+ & - & $0.56 \pm 0.03^{\mathrm{a}}$ \\
+ & $0.3 \mathrm{mM} \mathrm{AzC}$ & $0.28 \pm 0.02^{\mathrm{b}}$ \\
+ & $0.3 \mathrm{mM} \mathrm{AzC}+3 \mathrm{mM}$ proline & $0.42 \pm 0.03^{\mathrm{c}}$ \\
\hline
\end{tabular}

Alkaline phosphatase activity of RCT-1 was measured after treatment with $1 \mu \mathrm{M}$ retinoic acid for 4 days. For the experiments with collagen synthesis inhibitors, RCT1 cells were treated with $0.3 \mathrm{mM}$ L-azetidine-2-carboxylic acid (AzC) along with retinoic acid for 4 days. To reverse the inhibitory effect of $\mathrm{AzC}$ on collagen production, $3 \mathrm{mM}$ L-proline was added along with $\mathrm{AzC}$ and retinoic acid. Data are means $\pm \mathrm{SEM}$ of three determinations. Statistical significance was evaluated by an independent $t$ test. aSignificantly higher than cultures without treatments $(P<0.01)$. bignificantly less than cultures treated with $1 \mu \mathrm{M}$ retinoic acid alone $(P<0.01)$. 'Significantly higher than cultures treated with $1 \mu \mathrm{M}$ retinoic acid and $0.3 \mathrm{mM} \mathrm{AzC}(P<0.01)$. 


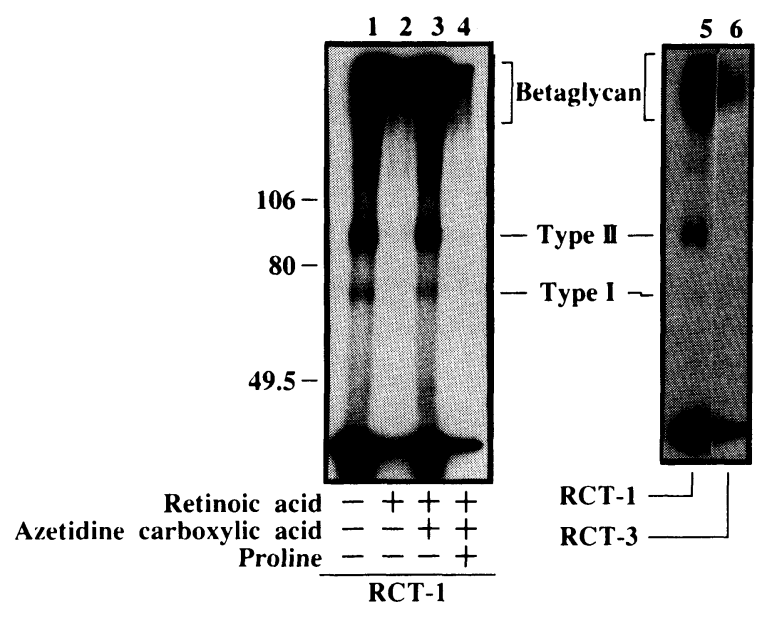

Fig. 2. Effect of an inhibitor of collagen production on TGF- $\beta$ receptors on RCT- 1 cells. Confluent RCT- 1 (lanes 1-5) and RCT-3 cells (lane 6) on 10-cm dishes treated with (lanes 2-4) or without (lanes 1, 5 and 6) $1 \mu \mathrm{M}$ retinoic acid for 4 days were incubated at $4{ }^{\circ} \mathrm{C}$ for $4 \mathrm{~h}$ with [ $\left.{ }^{125} \mathrm{I}\right] \mathrm{TGF}-\beta 1$ in the binding buffer containing $0.3 \%$ bovine serum albumin as described in "Materials and Methods". RCT-1 cells were also incubated with $0.3 \mathrm{mM}$ L-azetidine-2-carboxylic acid (lanes 3 and 4) along with $3 \mathrm{mM} \mathrm{L-proline} \mathrm{(lane}$ 4). Bound [ $\left.{ }^{125} \mathrm{I}\right] \mathrm{TGF}-\beta 1$ was chemically crosslinked with its receptors by $0.3 \mathrm{mM}$ disuccinimidyl suberate at $4{ }^{\circ} \mathrm{C}$ for $20 \mathrm{~min}$. After several washes, the cells were harvested, and TGF- $\beta$ receptors were extracted. Solubilized samples were analyzed by SDS-polyacrylamide gel electrophoresis with a $10 \%$ acrylamide gel under a reducing condition. Crosslinked receptors for TGF- $\beta$, types I and II and betaglycan, were visualized by autoradiography. Molecular weight standards are indicated in the left margin.

acid-induced osteoblastic differentiation of RCT-1 cells are similar to those observed during the process of differentiation of other mesenchymal [3] or premature osteoblastic cells [16] into osteoblasts. Because our previous study demonstrated that the differentiation process and the down-regulation of TGF- $\beta$ receptors in osteoblastic MC3T3-E1 cells are dependent upon collagen production [16], it is possible that collagen production is required for the down-regulation of TGF- $\beta$ receptors by retinoic acid in RCT-1 cells as well. In order to test this possibility, the effect of L-azetidine-2-carboxylic acid on retinoic acid-induced down-regulation of TGF- $\beta$ receptors was examined in RCT- 1 cells. As shown in Fig. 2, the inhibition of collagen production by L-azetidine-2-carboxylic acid almost completely blocked the reduction in cell surface TGF- $\beta$ receptors by retinoic acid, while the simultaneous addition of $3 \mathrm{mM}$ L-proline along with L-azetidine-2-carboxylic acid to recover collagen production eliminated the effect of the collagen inhibitor on TGF- $\beta$ receptors.

\section{Discussion}

Production of type I collagen is an essential early event associated with osteoblastic differentiation. Following the synthesis of type I collagen, sequential expression of markers of osteoblastic differentiation, such as ALP and osteocalcin, is observed, and osteoblasts acquire the ability to mineralize the synthesized matrix [13]. TGF- $\beta$ plays an important role in the synthesis of type I collagen and other matrix proteins [9] but, it strongly inhibits osteoblastic differentiation, and suppresses the expression of ALP $[11,16,18]$ and osteocalcin [12]. Therefore, if TGF- $\beta$ actions are not suppressed during the differentiation process, osteoblasts continue to accumulate matrix proteins but cannot further differentiate to mineralize the extracellular matrix. We have demonstrated that the development of ALP activity by long-term cultures of MC3T3-E1 osteoblastic cells is closely associated with down-regulation of TGF- $\beta$ receptors, and that both of the changes are dependent upon the interaction of accumulated collagen with cell-surface $\alpha 2 \beta 1$ integrin [16]. Although it is yet uncertain if the involvement of collagen in the down-regulation of TGF- $\beta$ receptors is specific to cells in an osteoblast lineage, it could be the case because active production and accumulation of type I collagen is a primary feature of osteoblasts at their early differentiation stage [13]. These results suggested that the accumulation of collagen matrix by osteoblasts themselves can inhibit TGF- $\beta$ actions and stimulate osteoblastic differentiation. However, it is not known whether retinoic acid-induced differentiation of osteoblasts is also affected by the interaction with collagen matrix.

In the present study, retinoic acid stimulated the expression of both type I collagen and ALP in RCT1 preosteoblastic cells, and the increase in ALP activity was associated with down-regulation of TGF- $\beta$ receptors. When collagen production was 
inhibited in the presence of retinoic acid, the decrease in TGF- $\beta$ receptors was almost completely blocked, while the increase in ALP activity was only partially suppressed. These observations imply that the down-regulation of TGF- $\beta$ receptors by retinoic acid is dependent upon the enhanced production and accumulation of type I collagen, but the stimulation of ALP expression is only partially dependent upon the production of collagen. A previous study demonstrated that retinoic acid rapidly and directly enhances transcription activity of the ALP gene promoterCAT construct transfected to RCT-1 cells, but the stimulation is only about 2 fold over the basal level [6]. From these results, it is plausible to assume that retinoic acid induces osteoblastic differentiation of preosteoblastic RCT-1 cells via at least three pathways; 1 ) direct transcriptional activation of differentiation-associated genes including ALP [6], 2) via the stimulation of type I collagen expression [5] that can also enhance the differentiation process of these cells, and 3) downregulation of TGF- $\beta$ receptors that suppresses the inhibitory effect of TGF- $\beta$ on osteoblastic differentiation (Fig. 2). Because TGF- $\beta$ has a potent inhibitory effect on the differentiation process of osteoblasts, the second and third indirect mechanisms mediated by the interaction between matrix collagen and osteoblastic cells may play an important role in the stimulation of osteoblastic differentiation by retinoic acid.

\section{Acknowledgements}

This work was supported in part by Grants-inAid for Scientific Research from the Ministry of Education, Science and Culture (Y.T., T.M.), Grants for the Silver Science Program on the Investigation of Osteoporosis from the Ministry of Health and Welfare of Japan (T.M.), and a Grant from the Research Society for Metabolic Bone Diseases (Y.T.).

\section{References}

1. Benayahu D, Fried A, Shamay A, Cunningham N, Blumberg S, Wientroub S (1994) Differential effects of retinoic acid and growth factors on osteoblastic markers and CD10/NEP activity in stromal-derived osteoblasts. J Cell Biochem 56: 62-73.

2. Franceschi RT, Iyer BS, Cui Y (1994) Effects of ascorbic acid on collagen matrix formation and osteoblast differentiation in murine MC3T3-E1 cells. J Bone Miner Res 9: 843-854.

3. Gazit D, Ebner R, Kahn AJ, Derynck R (1993) Modulation of expression and cell surface binding of members of the transforming growth factor- $\beta$ superfamily during retinoic acid-induced osteoblastic differentiation of multipotential mesenchymal cells. Mol Endocrinol 7: 189-198.

4. Harada S, Matsumoto T, Ogata E (1991) Role of ascorbic acid in the regulation of proliferation in osteoblast-like MC3T3-E1 cells. J Bone Miner Res 6: 903-908.

5. Heath JK, Rodan SB, Yoon K, Rodan GA (1989) Rat calvarial cell lines immortalized with SV-40 large $T$ antigen: Constitutive and retinoic acid-inducible expression of osteoblastic features. Endocrinology 124: 3060-3068.

6. Heath JK, Suva LJ, Yoon K, Kiledjian M, Martin TJ, Rodan GA (1992) Retinoic acid stimulates transcriptional activity from the alkaline phosphatase promoter in the immortalized rat calvarial cell line, RCT-1. Mol Endocrinol 6: 636-646.

7. Hock JM, Canalis E, Centrella M (1990) Transforming growth factor- $\beta$ stimulates bone matrix apposition and bone cell replication in cultured fetal rat calvariae. Endocrinology 126: 421426.

8. Ignotz RA, Massagué J (1986) Transforming growth factor- $\beta$ stimulates the expression of fibronectin and collagen and their incorporation into the extracellular matrix. J Biol Chem 261: 4337-4345.

9. Massagué J (1990) The transforming growth factor$\beta$ family. Annu Rev Cell Biol 6: 597-641.

10. Matsumoto T, Igarashi C, Takeuchi $Y$, Harada S, Kikuchi T, Yamato H, Ogata E (1991) Stimulation by 1,25-dihydroxyvitamin $\mathrm{D}_{3}$ of in vitro mineralization induced by osteoblast-like MC3T3E1 cells. Bone 12: 27-32.

11. Noda $M$, Rodan GA (1986) Type- $\beta$ transforming growth factor inhibits proliferation and expression of alkaline phosphatase in murine osteoblast-like cells. Biochem Biophys Res Commun 140: 56-65.

12. Noda M (1989) Transcriptional regulation of osteocalcin production by transforming factor- $\beta$ in rat osteoblast-like cells. Endocrinology 124: 612-617.

13. Stein GS, Lian JB (1993) Molecular mechanisms mediating proliferation/differentiation interrelationships during progressive development of the osteoblast phenotype. Endocrine Rev 14: 424-442. 
14. Takeuchi $Y$, Matsumoto $T$, Ogata E, Shishiba $Y$ (1989) 1,25-Dihydroxyvitamin $\mathrm{D}_{3}$ inhibits synthesis and enhances degradation of proteoglycans in osteoblastic cells. J Biol Chem 264: 18407-18413.

15. Takeuchi Y, Fukumoto S, Matsumoto T (1995) Relationship between actions of transforming growth factor (TGF)- $\beta$ and cell surface expression of its receptors in clonal osteoblastic cells. J Cell Physiol 162: 315-321.

16. Takeuchi Y, Nakayama K, Matsumoto T (1996) Differentiation and cell surface expression of transforming growth factor- $\beta$ receptors are regulated by interaction with matrix collagen in murine osteoblastic cells. J Biol Chem 271: 3938-3944.

17. Varga J, Rosenbloom J, Jimenez SA (1987) Transforming growth factor $\beta$ (TGF $\beta$ ) causes a persistent increase in steady-state amounts of type I and type III collagen and fibronectin mRNAs in normal human dermal fibroblasts. Biochem J 247: 597-604.

18. Wrana JF, Maeno M, Hawrylyshyn B, Yao KL, Domenicucci C, Sodek J (1988) Differential effects of transforming growth factor- $\beta$ on the synthesis of extracellular matrix proteins by normal fetal rat calvarial bone cell populations. J Cell Biol 106: 915924.

19. Zhou H, Hammonds R Jr, Findlay DM, Fuller PJ, Martin T J, Ng KW (1991) Retinoic acid modulation of mRNA levels in malignant, nontransformed, and immortalized osteoblasts. J Bone Miner Res 6: 767777. 